\title{
An investigation into the availability and role of oxygen gas in gold tailings dams of the Witwatersrand basin with reference to their acid mine drainage potential
}

\author{
AC Nengovhela ${ }^{1 *}$, B Yibas ${ }^{2}$ and JS Ogola ${ }^{1}$ \\ ${ }^{1}$ Department of Mining and Environmental Geology, University of Venda, Private Bag X 5050, Thohoyandou 0950, South Africa \\ ${ }^{2}$ Council for Geoscience, Private Bag X112, Pretoria 0001, South Africa
}

\begin{abstract}
The oxygen content of tailings dams around the Witwatersrand Basin was quantitatively measured over a period of 2 months using a multi-level gas sampling device (MLGS) in an attempt to understand the diffusion of oxygen in tailings dams as a result of acid mine drainage. The measured oxygen showed that the diffusion of oxygen in some Witwatersrand tailings dams is up to a depth of $4 \mathrm{~m}$. In some instances the oxygen content in the layer $1 \mathrm{~m}$ below the tailings surface decreased by a factor of more than $97 \%$ compared to the atmospheric content. The findings show that the development of oxidation zones in the tailings dams of Witwatersrand Basin which subsequently leads to acid mine drainage is limited by the amount of available oxygen in the tailings materials.
\end{abstract}

Keywords: oxygen, oxidation zone, acid mine drainage

\section{Introduction}

Over the past few years, there have been concerted efforts throughout the world to mitigate the impacts of mine waste deposits on the environment. If sustainable development is to be realised, the impacts of mine waste cannot be overlooked. This paper is a product of a research project funded by the Water Research Commission to Pulles Howard and De Lange (Yibas and Nengovhela, 2005).

The formation of acid mine drainage (AMD) from mine residue deposits is one of the major problems faced by the mining industry. It occurs when sulphide minerals in rocks and/or tailings are oxidised, usually because of exposure to moisture and oxygen (Ritchie, 2003). This paper presents results of the determination of oxygen availability in tailings dams. The generally accepted acid mine drainage equation below, shows that oxygen availability is a prerequisite in AMD generation (Davis et al., 1986).

$$
\mathrm{FeS}_{2}+7 / 2 \mathrm{O}_{2}+\mathrm{H}_{2} \mathrm{O} \rightarrow \mathrm{Fe}^{2+}+2 \mathrm{SO}_{4}^{2-}+2 \mathrm{H}^{+}
$$

The tailings deposit environment is a complex system of coupled physical and biogeochemical processes which can be divided into primary processes, for example water infiltration, watersaturation, oxygen diffusion, sulphide oxidation and secondary processes. Sulphides are consumed during oxidation, but it is assumed that their consumption leads to a negligibly small change in the bulk density of the material in the tailings. Oxygen consumed in the oxidation of sulphides leads to a change in gas composition, with a consequent change in gas density. It is further assumed that the quantity of gas dissolved in rain-

* To whom all correspondence should be addressed.

前 +27 76 926-8106; fax: 0187875972 ;

e-mail: colbert.nengovhela@goldfields.co.za

Received 24 August 2006; accepted in revised form 17 November 2006. water infiltrating the impoundment contributes a negligibly small amount to the flux of oxygen entering the impoundment (Ritchie, 2003).

Fine tailings are often deposited as slurry in a containing dam and allowed to settle. As diffusion of oxygen in air is approximately 4 times greater than in water, ingress of oxygen into tailings is relatively slow under water-saturated conditions. After closure of a tailings dam, or even during use, a decrease in the water level may lead to the formation of an unsaturated zone, thereby opening the way for oxygen diffusion in pore spaces, and hence faster oxidation processes (Lindvall and Eriksson, 2003).

The shape of an oxygen profile is controlled by the rate and manner in which oxygen diffuses or advects into the dam as well as the rate at which it is consumed within the dam. The consumption of oxygen results in the development of oxygen profiles that evolve over time as the oxidation process progresses (Ritchie, 1994). Several variables control the development of oxygen profiles and can be simplified as; the availability of oxygen, the quantity of pyrite and other sulphides, the rate of pyrite oxidation, the age of the dam, the buffer capacity of the dam rock, microbial activity, and the location of the profile on the dam (Ritchie, 1994; Forstner and Salomons, 1988).

Oxygen can be transported into the tailings deposit by three mechanisms, namely:

- Advective transport with water that contains oxygen

- Free or forced air convection through the top layer of the tailings deposit

- Diffusion in the gaseous and aqueous phases through pores in the tailings material (Werner, 2000).

The last mechanism is the dominant mechanism for transporting atmospheric oxygen from the surface of the tailings to the depth where the oxidation takes place (Jaynes et al., 1984; Nicholson et al., 1989; Pantelis and Ritchie, 1991; Yanful, 1993). Oxygen diffusion in the gaseous phase is often considered the main transport process for oxygen within the unsaturated zone. However, 
oxygen diffusion is sometimes conceptualised as a two-step process, with 'bulk diffusion' in the pore gas as the first step and aqueous-phase diffusion near and/or within the sulphide mineral grains as the second step (Davis and Ritchie, 1986).

The oxygen diffusion mechanism in either gas or water phase may be treated as one-dimensional. The oxygen diffusion rate in the unsaturated zone is high, relative to the saturated zone. Therefore, in the unsaturated zone, the sulphide oxidation rate may be relatively rapid, since the potential availability of both water and oxygen is large. Below the groundwater table, oxygen diffusion is greatly reduced, and the oxygen content will be limited to its solubility in water, which results in that sulphide oxidation should occur slowly below the groundwater table (Yanful, 1993).

Oxygen content inside a tailings dam varies depending on the degree of water-saturation, temperature, the rate of water infiltration and the rate of oxygen consumption. Elberling et al. (1993) conducted field studies on uncovered unsaturated tailings deposits in Canada. They reported that the pore gas oxygen content decreased from atmospheric contents (21 vol \%) to less than 5 vol \% within the upper $600 \mathrm{~mm}$ of the tailings dams In water-saturated conditions, the oxygen content is limited to the solubility of oxygen in water, or $258 \mu \mathrm{M}$ at $25^{\circ} \mathrm{C}$ (that is 21 vol \%).

\section{Materials and methods}

\section{Study area}

Six sites, distributed across the Witwatersrand Basin were selected for this study (Fig. 1). One in the Stilfontein area, two in the Carletonville area on the border between Gauteng and North West Provinces, one in the Central Rand area of the Witwatersrand Basin and the last two in the East Rand area of the Witwatersrand Basin. The sampling was carried out between April and June 2005. The characteristics of the 6 dams are summarised in Table 1.

\begin{tabular}{|l|c|c|c|c|}
\hline \multicolumn{5}{|c|}{ TABLE 1 } \\
Summary of available background information for \\
the selected dams
\end{tabular}

\#Unavailable information.

\section{Instrumentation}

The instrument used for the measurement of oxygen is known as the Gas Alert Max, from BW Technologies. This instrument pumps $\mathrm{O}_{2}$ at a rate of $250 \mathrm{~m} \ell / \mathrm{min}$ (minimum). Its detection range for oxygen is 0 to $30 \%$ in 0.1 increments and it uses a plug-in electrochemical cell sensor type. The $\mathrm{O}_{2}$ measuring principle used is the capillary-controlled content sensor that comes with an automatic calibration system. At each dam, a multilevel gas sampling system (MLGS) adopted from Shaw (2004) was con-

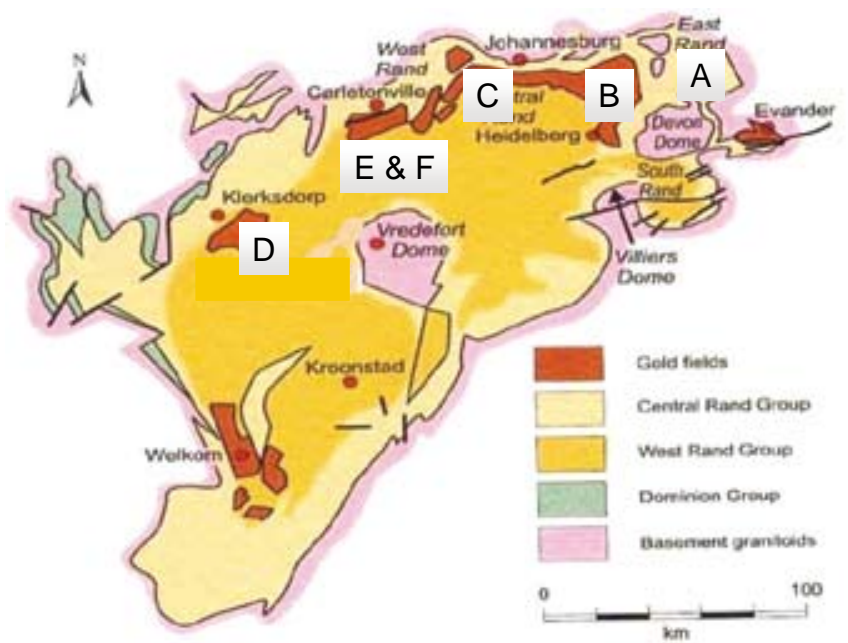

Figure 1

Location map of all the study sites showing their spatial distribution across the Witwatersrand Basin (Gold Fields, Driefontein Gold Mine, 2004)

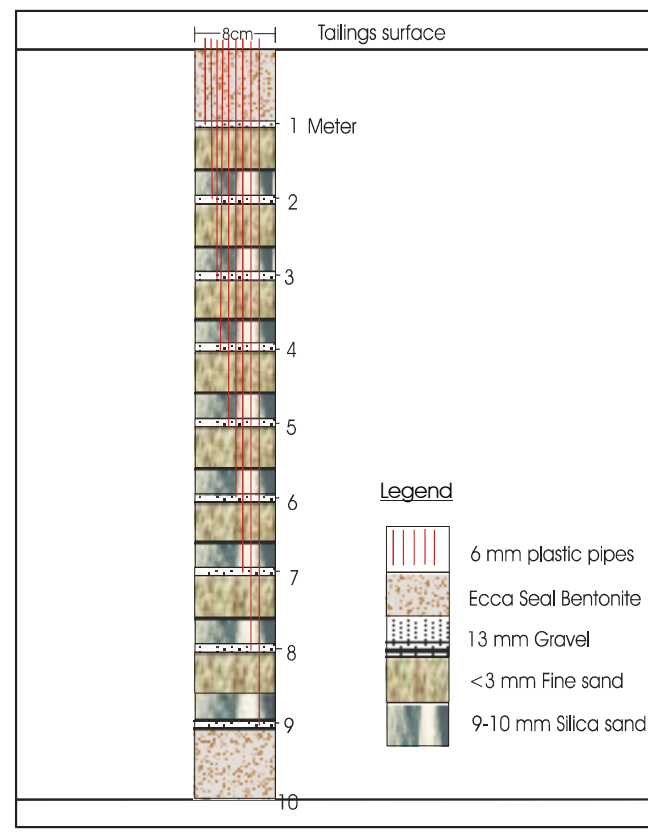

Figure 2

Schematic diagram of the MLGS demonstrating the alternating layers of gravel, coarse and fine-grained sand used to promote horizontal pore-gas flow. The pipes are placed at $1 \mathrm{~m}$ intervals up to the bottom of the hole, i.e. $9 \mathrm{~m}$.

structed using 9 × $6 \mathrm{~mm}$ diameter polyethylene sample tubes per dam. This device has a built-in pipe, which allows for the gas to be pumped from the various depths (Fig. 2). The inlets of the sample tubes were placed between $200 \mathrm{~mm}$ thickness of $13 \mathrm{~mm}$ diameter gravel stones, i.e. $100 \mathrm{~mm}$ below and $100 \mathrm{~mm}$ above the port to prevent particulate uptake and to prevent clogging of the sample tubes.

The MLGS was installed in holes made by a hand auger of $80 \mathrm{~mm}$ diameter. The well screen at the bottom of the centre stock extended to a depth of $10 \mathrm{~m}$ with a $900 \mathrm{~mm}$ bentonite layer between the $9 \mathrm{~m}$ and $10 \mathrm{~m}$ level to minimise vertical air flow from the bottom of the tailings dams.

Fine-grained sand ( 0.2 to $0.3 \mathrm{~mm}$ ) was placed in between 


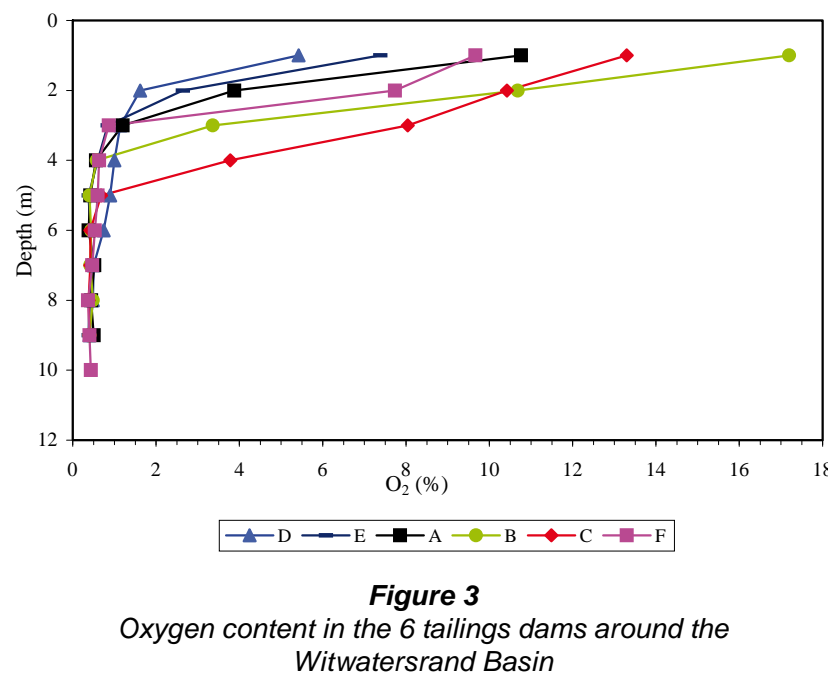

each sampling port for a width of $600 \mathrm{~mm}$ to minimise the vertical movement of pore gas. Coarse-grained sand $(0.8$ to $1.0 \mathrm{~mm})$ was placed immediately above the $20 \mathrm{~mm}$ of gravel for a width of $30 \mathrm{~mm}$ to promote horizontal flow of the pore-gas. At the tailings surface the annular space in the drill hole was sealed to $900 \mathrm{~mm}$ depth with bentonite. Due to the age of the dams, and the fact that they were being reclaimed, no water table was encountered at any of the sites. One hole per dam was drilled for the insertion of the MLGS which means that the data collected results from one profile of the dam.

\section{Results and discussion}

Oxidation of sulphide minerals in mine waste deposits is controlled by the supply of oxygen. Diffusion in the air filled part of the pore system above the phreatic surface is usually considered to be the dominant transport mechanism for oxygen. Hence, the formation of oxidation zones in tailings deposits is strongly dependent on the oxygen flux by diffusion. Relevant quantification of oxygen diffusion is therefore a key factor in the design and assessment of prediction and prevention of AMD (Nengovhela, 2006).

Site A shows a decreasing pattern of oxygen content and depletion throughout the $9 \mathrm{~m}$ depth (Fig. 3). Differences in oxygen contents are only found within the top $3 \mathrm{~m}$ after which there is no variation until the end of the sampled depth. The average oxygen content at the $1 \mathrm{~m}$ level is $10.76 \%$, which is a decrease by a factor of $48 \%$ from the atmospheric content (21\%). The abrupt decrease from the $1 \mathrm{~m}$ level to $2 \mathrm{~m}$, i.e. from 10.76 to $3.88 \%$ means that there is high oxygen consumption in the top part of the dam. From $2 \mathrm{~m}$ to $3 \mathrm{~m}$, the decrease is from $3.88 \%$ to $1.2 \%$, which is a $69 \%$ decrease. This means the decrease from the atmospheric content of oxygen to the $3 \mathrm{~m}$ level is by $94.3 \%$. The drop in oxygen gradient at this site is around $60 \% / \mathrm{m}$ for the first $3 \mathrm{~m}$.

Site B is slightly different from Site A in that its average oxygen content in the oxidation zone is almost twice that of Site $\mathrm{A}$ at $17.2 \%$. This is the highest oxygen content in all the oxidation zones of the sampled sites. Although the first metre contains the highest oxygen of all the sites by far, the content drops by $38 \%$ at the second metre level. In Site B, the decline from the atmospheric oxygen content to the first metre in the oxidation zone is by $18.09 \%$ which is the lowest of all the other dams. This suggests that the dam's material is highly diffusive at the top of the dam. The significantly high percentage of oxygen at this dam comes to an end at the $4 \mathrm{~m}$ level where there is a decrease by $84 \%$ from the atmospheric content. This shows that there is little oxygen beyond the $3 \mathrm{~m}$ level. Comparing this site to Site A, its oxygen content at the $4 \mathrm{~m}$ level is $48 \%$ less than that of Site A.

The $3^{\text {rd }}$ site, i.e. $\mathrm{C}$ is the only site that has an oxygen content of higher than $3 \%$ below the $3 \mathrm{~m}$ mark. It contains significant oxygen at the $4 \mathrm{~m}$ level of $3.78 \%$, which is relatively high, compared to all the other sites, which normally have levels of between 0.6 and $1.2 \%$ at this level.

Site D has the lowest oxygen level of all the dams at 5.42\% within the first metre, which decreases to $1.62 \%$ at the $2 \mathrm{~m}$ mark (Fig. 3). The drop from the atmospheric content of $21 \%$ to $5.42 \%$ is by $74 \%$. The decline from 1 to $2 \mathrm{~m}$ is by $70 \%$. This point shows that at Site $\mathrm{D}$, the rate of oxygen depletion is approximately $72 \%$ within the first $2 \mathrm{~m}$.

Site $\mathrm{E}$ is the youngest site of all the dams (decommissioned in 1997). Its oxygen content at the $1 \mathrm{~m}$ level is only $7.38 \%$, which is significantly less than the oxygen content of the $3 \mathrm{~m}$ level of Site C. The drop from the atmospheric content to the first metre is by $65 \%$. From the first metre to the second, the oxygen is depleted by $64 \%$. At the $3 \mathrm{~m}$ level, from which relatively constant contents of oxygen begin, the gradient is $68 \%$ from the $2 \mathrm{~m}$ level.

Site F is located within $5 \mathrm{~km}$ of Site E. It is slightly older than the latter and most of its surface is covered with vegetation. This site contains the third lowest oxygen content with the first metre only having a content of $9.67 \%$. The oxygen content decreases below $1 \%$ at the $3 \mathrm{~m}$ level and remains constant to the end of the sampled depth then decreases up to the $8 \mathrm{~m}$ level before it stabilises below this level.

From the data presented it can be observed that the oxygen contents in the first $10 \mathrm{~m}$ of the 6 studied tailings dams varied between 0.36 and $17.2 \%$ over the eight-week sampling period from April to June 2005. Within each tailings dam, oxygen contents remained relatively constant between 3 and $10 \mathrm{~m}$, which indicates that there is little change in oxygen content below $3 \mathrm{~m}$, which explains the reported average oxidation zone of 2.5 m. Previous studies (Yanful, 1993, Davis et al, 1986) of tailings dams have demonstrated that the consumption of pore-gas $\mathrm{O}_{2}$ through in-situ reactions results in decreasing $\mathrm{O}_{2}$ contents with depth when transport is controlled by the vertical diffusion of $\mathrm{O}_{2}$ from the atmosphere.

\section{Conclusions}

From this study, it can be concluded that oxygen depletion in the studied Witwatersrand tailings dams occurs rapidly from the atmosphere to the first few metres of the studied tailings dams. The conclusion generated from the calculated average depletion gradient of all the dams is that the drop between the atmospheric oxygen level of $21 \%$ and the level of $0.56 \%$ at a depth of $5 \mathrm{~m}$ is $97 \%$ as shown in Fig. 3. At a depth of $1 \mathrm{~m}$ where sulphide oxidation is active, the average oxygen content is $10.67 \%$ and decreases by $88.5 \%$ at $4 \mathrm{~m}$ to $1.23 \%$. The progressive decrease in oxygen from 1 to $2 \mathrm{~m}$ is by $43.29 \%$ and at $3 \mathrm{~m}$ it decreases again by a factor of $55.54 \%$ from the $2 \mathrm{~m}$ level. From 3 to $4 \mathrm{~m}$, the gradient declines by $54.37 \%$, which shows that there is a significant difference between $3 \mathrm{~m}$ and $4 \mathrm{~m}$ levels. From 4 to $5 \mathrm{~m}$ there is a decrease of $54.47 \%$ in oxygen, which remains generally constant until the end of the $9 \mathrm{~m}$ sampled depth. This means that below a depth of $4 \mathrm{~m}$, there is no longer any variation in the amount of oxygen contained by the tailings dams. The overall oxygen depletion gradient within the first $5 \mathrm{~m}$ is an average of $52 \%$. Most changes occur in the top part of the dam where the 
availability of oxygen and water is high.

Oxygen in the studied tailings dams varies from $0.36 \%$ in the reducing zone to $17.2 \%$ in the oxidation zone. Considerable oxygen is only found in the top $4 \mathrm{~m}$ of the Witwatersrand tailings dams. There is no significant variation in oxygen content between 4 and $10 \mathrm{~m}$. The flux of oxygen into the tailings is controlled by diffusion in the gaseous and aqueous phases through pores in the tailings material.

Oxygen flux is strongly controlled by diffusion in the gaseous and aqueous phases through pores in the tailings material from the atmospheric content. This means that as long as the tailings materials of the Witwatersrand remain sandy silt to silty sand, oxidation zone development will be limited to the top 3 $\mathrm{m}$. This point shows that the tailings material that is prone to oxidation and consequently acid mine drainage generation in the Witwatersrand tailings dams is limited only to the first $4 \mathrm{~m}$. Since some of the dams studied are older than 30 years, it can be concluded that oxygen diffusion in tailings dams is limited to the top $4 \mathrm{~m}$ of a tailings dam. This is because, as was observed in Site E for instance, that despite having been decommissioned 10 years ago, it had a similar oxygen profile to a dam such as Site A that was decommissioned 50 years ago, for instance, Site A. The age of a tailings dam does not appear to have a significant bearing on the severity of oxidation zone development and subsequent acid mine drainage.

\section{Acknowledgements}

This paper resulted from a research project funded by the Water Research Commission of South Africa to Pulles Howard de Lange Inc (PHD) (now part of Golder and Associates). The first author has also used the project for his M.Sc. study in the Department of Mining and Environmental Geology, University of Venda. The authors also wish to acknowledge Professor Baojin Zhao (University of Fort Hare, Geology) for his contribution to the research.

\section{References}

DAVIS GB and RITCHIE AIM (1986) A model of oxidation in pyretic mine wastes, 1, Equations and approximate solutions. Appl. Math. Model. 10 314-322.

ELBERLING B, NICHOLSON RV and DARREN DV (1993) Field evaluation of sulphide oxidation rates. Nordic Hydrol. 24 (5) 323-338.
FORSTNER U and SALOMONS W (eds.) (1988) Environmental Management of Solid Waste. Springer-Verlag, Berlin and Heidelberg, Germany.

GOLDFIELDS, DRIEFONTEIN GOLD MINE, GEOLOGY DEPARTMENT (2004) Geology of Driefontein Gold Mine, Unpublished.

JAYNES DB, PIONKE HB and ROGOWSKI AS (1984) Acid mine drainage from reclaimed coal strip mines, 2. Simulation results of model. Water Resour. Res. 20 243-250.

LINDVALL M and ERIKSSON N (2003) Investigation of weathering properties of tailings sand from Boliden's Aitik copper mine, Sweden - A summary of twelve years of investigations. Proc. ICARD 2003, $6^{\text {th }}$ Int. Conf. on Acid Rock Drainage. Cairns, Australia, July 14-17, 2003. 725-731.

NENGOVHELA AC (2006) A Comparative Study of the Development and Characterisation of Oxidation Zones of Witwatersrand Gold Mines' Tailings Dams. Unpublished M.Sc. thesis, University of Venda.

NICHOLSON RV GILLHAM RW CHERRY JA and REARDON EJ (1989) Reduction of acid generation in mine tailings through the use of moisture-retaining cover layers as oxygen barriers. Can. Geotech. J. 26 1-8.

PANTELIS G and RITCHIE AIM (1991) Macroscopic transport mechanisms as a rate-limiting factor in dump leaching of pyretic ores. Appl. Math. Model. 15 136-143.

RITCHIE AIM (1994) Sulfide oxidation mechanism - Control and rates of oxygen transport. In: Jambor JL and Blowes DW (eds.) The Environmental Geochemistry of Sulfide Mine-Waste. Mineralogical Association of Canada, Short Course Handbook 22. 210-245.

RITCHIE AIM (2003) Oxidation and gas transport in piles of sulfidic material. In: Jambor JL, Blowes DW and Ritchie AIM (eds.) Environmental Aspects of Mine Waste. Mineralogical Association of Canada, Short Course Series, Volume 31. Vancouver British Colombia. 77-94.

SHAW SA (2004) Determining the Long Term Persistence of Mercury Releases to the Environment from Cyanide-Rich Gold Mine Tailings. Unpublished M.Sc. Thesis. The University of New Brunswick, New Jersey, US.

WERNER K (2000) Soil-Cover Remediation of Mill Tailings Deposits: Effects on Oxygen Transport and Hydrological Conditions. Licentiate Thesis. Division of Water Resources Engineering, Department of Civil and Environmental Engineering, Royal Institute of Technology, Stockholm, Sweden. 111 pp.

YANFUL EK (1993) Oxygen diffusion through soil covers on sulphidic mine tailings. J. Geotech. Eng. 119 1207-1228.

YIBAS B and NENGOVHELA C (2005) Oxygen profiles in gold tailings dams (Report to the WRC Deliverable 4): Development of oxidation zones in tailings dams with specific reference to the Witwatersrand gold mine tailings dams. WRC Project No. K5/1554. 